\title{
Potency and Conservation of Aren (Arenga pinnata (Wurmb) Merr.) in Meru Betiri National Park, East Java-Indonesia
}

\author{
Ervizal A. M. Zuhud ${ }^{1}$, Primadhika Al Manar ${ }^{1 *}$ Zuraida $^{2}$, Syafitri Hidayati ${ }^{1}$ \\ ${ }^{1}$ Department of Forest Resources Conservation and Ecotourism, Faculty of Forestry and Environment, IPB University, \\ Academic Ring Road, Campus IPB Dramaga, Bogor, Indonesia 16680 \\ ${ }^{2}$ Forest Research and Development Center, Ministry of Environment and Forestry, Bogor, Indonesia
}

Received January 19, 2020/Accepted September 20, 2020

\begin{abstract}
Aren (Arenga pinnata (Wurmb) Merr.) is a high ecological and economical value species of Indonesia. Aren grows spreading in Indonesia including at Meru Betiri National Park in the province of East Java, Indonesia. The community in Meru Betiri National Park uses aren fruit which is called kolang-kaling. Even though aren grows naturally in this area, the community has not maximized its utilization. This study aims to identify the actual and ideal conditions for aren conservation also to analyse the gap between them, and to formulate the conservation actions to realize a sustainable aren conservation in Meru Betiri National Park. The data wascollected by using vegetation analysis and in-depth interviews with all of the aren farmers. Aren regeneration in Meru Betiri National Park is categorized stable and seems to be decreased. The use of aren by the community is limited only from the fruit as kolang-kaling. There is a gap between current and ideal conditions for achieving aren sustainability. To achieve the ideal conditions, conservation actions are needed among aren farmers by utilizing agroforestry systems, increasing the value of aren, intensive coaching for aren farmers, and forming a group of aren farmer
\end{abstract}

Keywords: community, conservation efforts, conservation strategy, ethnobotany

*Correspondence author, email:primadhikaa@gmail.com

\section{Introduction}

Aren (Arenga pinnata (Wurmb) Merr.) is a species of the Arecaceae family with high economical and ecological values. Community has used aren for various needs (Haryoso et al., 2020) such as for sugar, sweets, building materials, baskets, handicrafts, and roofs (Ishak et al., 2013). As a nontimber forest product, community can utilize many parts of aren tree such as root, stem, leaf, ijuk, nira water, starch, and fruit (Sahari et al., 2013; Gunawan et al., 2018). However, aren is commonly known useful as food plants (Sumarni et al., 2003; Sovia \& Anggraeny, 2019), producing starch commodities (carbohydrates) such as flour, aren sugar (palm sugar), and fruit (kolang-kaling) (Kemenhut, 2007).

Aren grows in Southeast Asia from South China to Ryukyu Island in northern, Christmas Island in southern, India in western, and to Queensland, Australia in eastern (Pongsattayapipat \& Barfod, 2009; Dransfield et al., 2014). In Indonesia, aren grows in almost all regions, especially in hills area with high humidity (Sunanto, 1993) such as North Sumatera, West Sumatera, Bengkulu, Banten, West Java, Central Java, East Java, South Kalimantan, East Kalimantan, North Sulawesi, South Sulawesi, East Nusa Tenggara, Maluku, and Papua (Lay \& Karouw, 2006).

Meru Betiri National Park (MBNP) in East Java is an aren plantation site characterized by a nature conservation area with an original ecosystem. The national park is managed by a zoning system, consisting with: core zone, rimba zone, utilization zone, and other zones (e.g., marine protection zone; traditional zone; rehabilitation zone; religious, culture, and history zone; and special zone) (KLHK, 2015). Yet, in Meru Betiri National Park, aren commonly found in its rimba zone. This zone is part of a national park that is determined because of its location and conditions which become a potential support of conservation in the core and utilization zone (KLHK, 2015). One of the activities that may be carried out in the rimba zone is the utilization of germplasm resources to support cultivation activities, but not for economic activities. Based on these facts, it is necessary to educate the local community for cultivating aren in rehabilitation area, so that aren utilization can be sustainable.

The community in Meru Betiri National Park uses aren fruit which is called kolang-kaling. The widespread use of aren is feared to cause scarcity considering its long harvesting time, around 7-12 years (Manaroinsong et al., 2006). Aren is currently not a priority to be developed, due to a lack of current cultivation technology to proliferate. Limitations of the information and skill about cultivation techniques become the most important factor which creates reluctance among aren farmers. Second, the potential of aren has not been widely known by the community, especially people who are living around Meru Betiri National Park. 
Even though aren grows in this area, the community has not taken full advantage of this species. Therefore, the aims of this study are: 1) to identify the actual condition of aren conservation, 2) to determine the ideal conditions for aren conservation, 3) to analyse the gap between the actual and ideal conditions, and 4) to formulate the conservation actions to realize a sustainable aren conservation in Meru Betiri National Park.

\section{Methods}

Time and location This research was conducted in March 2019 at Andongrejo Resort, Meru Betiri National Park, Jember, East Java, Indonesia (Figure 1). Geographically, Meru Betiri National Park is located at S8 $20^{\prime} 48^{\prime \prime}-\mathrm{S} 8^{\circ} 33^{\prime} 48^{\prime \prime}$ and E113'38'38"-E113'58'30". Administratively, Meru Betiri National Park area is located in Jember Regency and Banyuwangi Regency, East Java Province, Indonesia. The topography of this area is hilly with a range of elevations starting from the edge of the sea to altitude of 1,223 $\mathrm{m}$ above sea level (the top of Mount Betiri). The rainfall rate on this region is varied between 2,544 and 3,478 mm year ${ }^{-1}$ with wet months between November and March, and dry months between April and October (BTNMB, 2009).

Data collection Data was collected by using vegetation analysis and in-depth interviews, collaborate with all aren farmers in Andongrejo. Vegetation analysis was carried out to identify the potential of aren regeneration in Meru Betiri National Park by comparing each level of growth of the aren plants (seedlings, saplings, poles, and trees). The observation plot was selected by using purposive sampling with specific criteria (Sugiyono, 2017) based on the locations of aren. The sample plot size is $20 \times 20 \mathrm{~m}$. The total area of the observation plot is 0.4 ha, due to the slope of the study site and the limits of the measurements area. The location was a place used by the community to harvest the aren fruit.

Aren is commonly found in the rimba zone of the Meru Betiri National Park. The observation plot was made by cutting the contour direction of the first aren tree found. Data collection for each growth level referred to Permentan Number $133 / 2013$, i.e. seedling $=$ clear $\operatorname{wood}^{1} 0<0.5 \mathrm{~m}$; saplings $=$ clear wood $0.5-1.5 \mathrm{~m}$; poles $=$ clear $\operatorname{wood} 1.5-3$ $\mathrm{m}$; trees $=$ clear wood $>3 \mathrm{~m}($ Kementan, 2013).

In-depth interviews were conducted with 13 aren farmers, all of them are male. Female farmers were not found, probably due to the nature of activities in producing kolang-kaling. A long time in harvesting and a far distance between the house to the forest are perceived difficult to be conducted by women. In addition, the harvesting activities require stronger energy to climb the aren tree. This condition was also reported by Sugihartono (2007), that gender determines a person's level of participation and productivity at work.

During interviews, the questions investigated the local knowledge and perceptions of aren conservation (Febriyanti, 2017). By considering the actual condition, some questions were raised to complete the gap between the current and ideal condition, such as the potential of aren fruit ( $\mathrm{kg}$ per month),

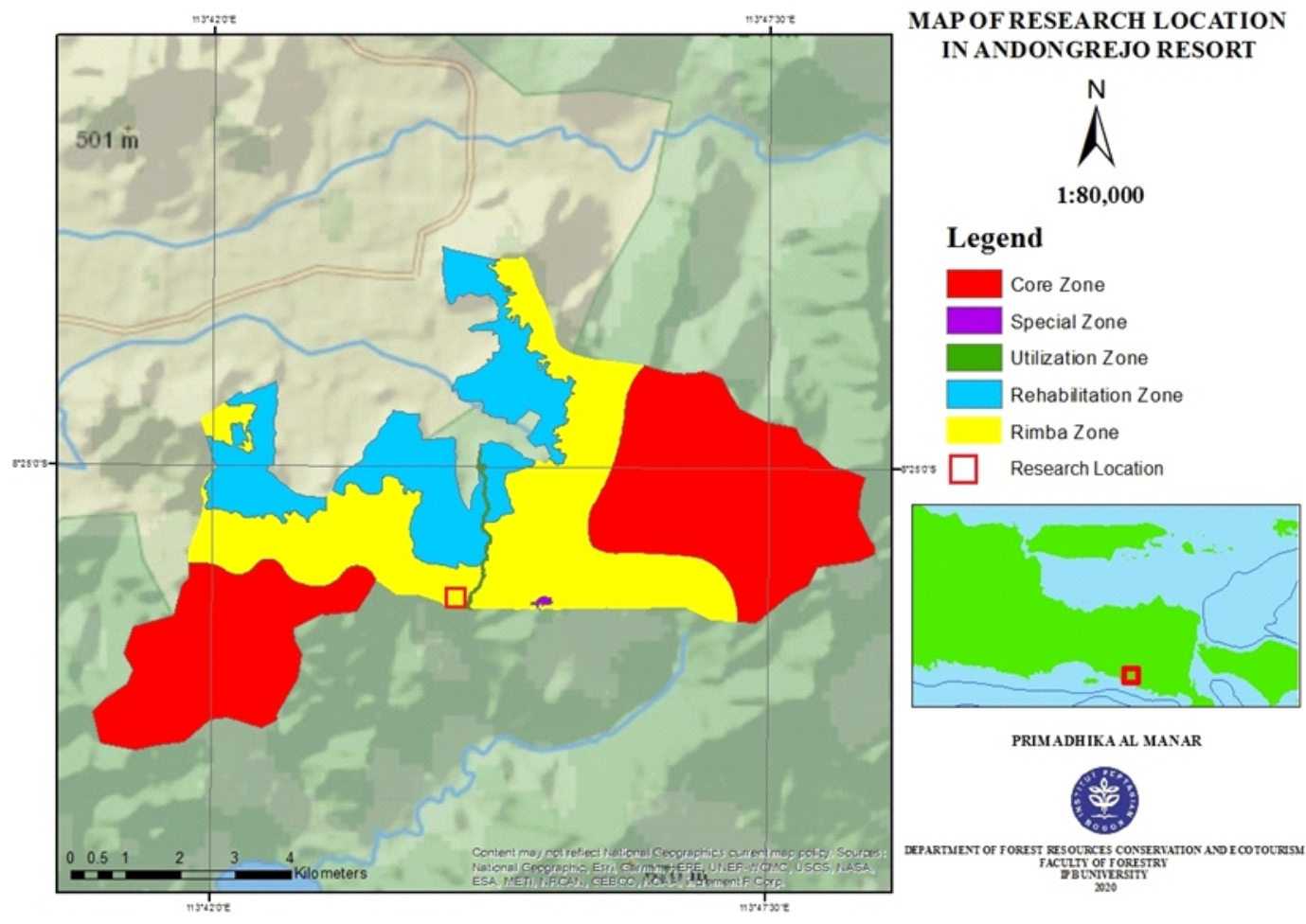

Figure 1 Research site in Andongrejo Resort, Meru Betiri National Park.

${ }^{1}$ Measures from the soil line to the highest point without frond bases. 
the farmer income from aren fruit (IDR per harvest cycle), the cause of aren planting failure in rehabilitation zone, and the marketing of aren products.

Aren conservation strategies was analysed using the theory of Tri-Stimulus Amar Pro Konservasi, according to Zuhud (2007). The precondition for the realization of successful conservation is the creation of attitudes and behaviours that are strongly driven by Tri-Stimulus Amar Pro Konservasi: crystallization or the unity of natural stimulus (stimulus alami), benefit stimulus (stimulus manfaat), and religious-willing stimulus (sitimulus religius-rela) (Zuhud, 2007). A natural stimulus is a reflection of the truth values of nature, needs, and sustainability of living natural resources by their bio-ecological character. Benefit stimulus is a reflection of the values of interests for humans (economic, social, biological/ecological benefits, etc.). A religiouswilling stimulus is a stimulus that encourages someone to be willing to carry out conservation activities such as the highest value in the form of goodness especially the rewards from the creator of nature, spiritual values, universal religious values, merit, happiness, wisdom and culture/traditional, inner satisfaction, and others.

\section{Results and Discussion}

Aren regeneration in Andongrejo Resort A vegetation analysis of aren conducted on 0.4 ha observation plot in Andongrejo, obtained 208 individuals consisting with seedlings, saplings, poles, and trees. Aren density at each growth level is presented in Table 1.

Table 1 shows the density of aren at Andongrejo Resort is stable, showed by the number of seedlings are higher than saplings, poles, and trees. Aren density at each growth level can be used as an indicator of aren natural regeneration level. Differences in the density value of each growth level are caused by variety reproductive ability, distribution, and adaptability to the environment (Arrijani et al., 2006). The density value of a species indicates the number of individual species concerned at a certain unit area. The structure of plant populations changes over time, yet the significant factors of population structure changes is a human activity that is less concerned with replanting of the species (Surasana \& Taufikurrahman, 1994).

Aren trees in Andongrejo Resort area are utilized by the

Table 1 Density of aren at each growth level

\begin{tabular}{lcccc}
\hline \multirow{2}{*}{ Growth level } & $\begin{array}{c}\text { Large plot } \\
\text { (ha) }\end{array}$ & Total & Density & Frequency \\
\cline { 3 - 5 } & & & $\left(\mathrm{N} \mathrm{ha}^{-1}\right)$ & \\
\hline Seedlings & 0.4 & 56 & 215 & 0.8 \\
Saplings & & 46 & 130 & 0.8 \\
Poles & & 28 & 715 & 0.9 \\
Trees & & & 70 & 0.9 \\
\hline
\end{tabular}

surrounding community who took aren fruit. Therefore, since aren plants spreading new individuals through the seeds in the fruits, there is a concern about the future numbers of seedlings, saplings, poles, and trees.

Seeds distribution of certain plants is carried out by animals such as birds, monkeys, squirrels, bats, and civets through their feces (Ewusie, 1990). Forest regeneration is naturally greatly assisted by animals with seeds being ingested or swallowed and then spread through animal feces (Setia, 2008). Aren seeds are spread by civet through their feces. Civets can help to break the seed dormancy, so that the aren seeds can grow and develop to be seedlings. Seeds that have been eaten by wild animals will germinate faster due to the gastric fluid which has a $\mathrm{pH}$ of 2 (Weisz, 1959). The liquid in the stomach is acidic, so it can help to soften the hard seed coat. Comparison of aren density at each growth level presented in Figure 2

The state of sampled species regeneration was assessed based on one-time phytosociological data in the following categories: (a) 'good', if the numbers of seedling > sapling > adult; (b) 'fair', if the numbers of seedling > sapling > adult; (c) 'poor', if a species survives in only sapling stage, but not as seedlings (though the numbers of saplings may be less, more or equal than adults); (d) 'none', if a species is absent both in sapling and seedling stages, but present as adults; and (e) 'new', if a species has no adults, but only saplings and/or seedlings (Shankar, 2001). Aren regeneration at the research site is included in good category as the total number of seedlings is greater than saplings, poles, and trees.

Natural regeneration in forest stands can occur through natural seed distribution by stands. Naturally the process occurs when the seeds fall down to the forest floor, then it develops into a seedling. Factors that influence seedling development in nature include root development, light conditions, soil conditions, competition, plant composition, biotic factors, such as grazing, fires, and other factors such as rainfall, long dry season, and extreme temperatures (Wanggai, 2009).

Aren distribution in Tumpak Gesing Block Aren found in the research site is located mostly on the cliffs. The plant can be grown on steep, almost vertical, and slopes (Muda et al., 2016; Yusof \& El Pebrian, 2016). Aren found at altitude of

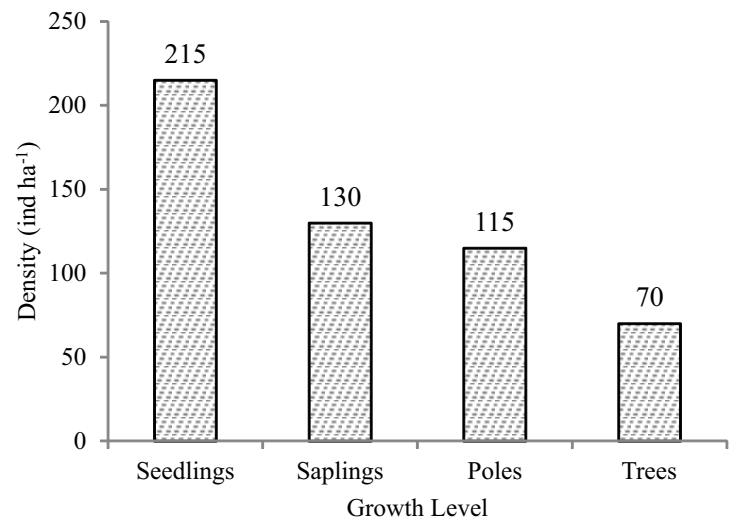

Figure 2 Comparison of aren density. 
$300500 \mathrm{~m}$ above sea level which is suitable for the species (Soeseno, 1991). Aren generally grows in groups along the Andongrejo-Bandealit route. This is in accordance with the statement that aren plants can grow individually or in groups (Alam \& Suhartati, 2000). The distribution of a type is influenced by environmental factors where the species grows. Aren is generally located on the edge of a cliff and hill, rarely found on soils with gently sloping topography. Air humidity in the research area ranged between $91 \%$ and $93 \%$ which is included in the category of high so that the location is a suitable habitat for the natural growth of aren. Aren is spread in almost all regions of Indonesia, especially in humid hilly areas (Sunanto, 1993). Aren distribution at Andongrejo Resort is presented in Figure 3.

Plants in their early stages of life have a high sensitivity to the environment (Krebs, 1989). Factors that limit the distribution of the plants include the climate, edaphic factors, and interactions with other plants. Therefore, plant populations in nature generally spread in clusters and only slightly spread in other patterns. Aren found at the study site generally spreads in groups. Factors that can influence the spatial patterns of living things are: (a) vectorial factors, produced by environmental actions (soil type, wind, light, and water intensity), (b) social factors, related to the behavior of organisms such as territorial, (c) co-active factors, related to intraspecific interactions, and (d) stochastic factors, resulted from random variations in some of the previous factors (Ludwig \& Reynolds, 1988).

Utilization of aren Formerly, the community of Andongrejo Village utilizes aren to take nira water as raw material for making aren sugar, but the present study conclude that the community of Andongrejo Village is only taking aren fruit (kolang-kaling). The community only utilizes aren fruit because it can be directly sold to the middleman and get instant cash for daily needs. Taking of aren fruit by the community usually requires quite a long time because it is quite difficult to obtain aren fruit that is ready to be harvested. The community that utilizes aren have to spend the night in the forest to get aren fruit that is ready to be harvested. That is caused a total of aren trees that bear fruit is getting smaller while aren trees take 7-12 years to bear fruit.

Aren fruit taken by the community has to fulfill an age criteria, means not to old and not too young (cemukil). Aren fruit that is cemukil has a characteristic of not sticky and not too hard. If the aren fruit is too old, it will produce a hard fruit texture in the processing. As a result, it is considered has a low quality. On the other hand, if the fruit is too young, the processing of the fruit texture will be too soft and make it difficult to be further processed (Purwati \& Nugrahini, 2018). To determine the aren fruits that are ready to be harvested, a specific skill is required.

The process of producing kolang-kaling is started by boiling aren fruit in clean water for 2 hours until it well cooked. After the aren fruit is boiled, the next process is to split the endosperm of aren fruit seeds with the skin of aren fruit using golok. The process of making kolang-kaling is carried out by the community directly at the location of taking aren fruit, so that kolang-kaling is ready to be sold to the middleman. This was done to facilitate the transportation of aren fruit harvest from collection location to the village. After aren fruit is peeled, the next process is soaking kolangkaling with clean water with a purpose of eliminating the sap (Sunanto, 1993). The sap of aren fruit can cause itchy because it contains calcium oxalate crystals that can pierce human skin cells (Widyawati, 2011). Kolang-kaling should not be exposed to rain or saltwater to retain its white color

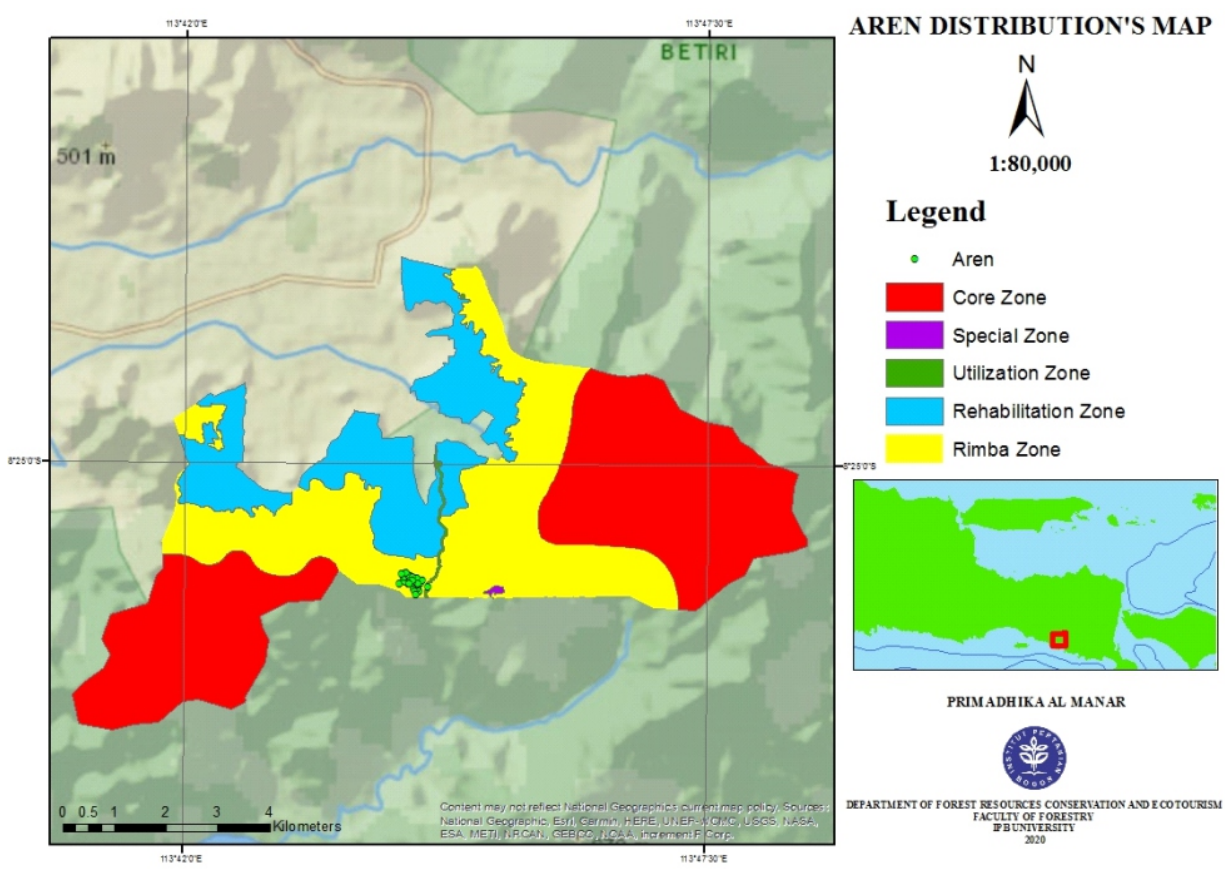

Figure 3 Aren distribution in Andongrejo Resort. 
(cemeng).

One adult aren tree can produce about 5-10 aren fruit bunches. Each aren fruit bunch could consist of hundreds of aren fruits. Harvesting one mature aren tree takes 1 month, for a total of 4 times. A large and fertile aren tree can produce 1 to 2 quintals of fruit in one harvest cycle. Each aren tree is harvested by one aren farmer until the end of the harvest cycle, so there is no competition for aren tree harvesting between aren farmers. The current selling price of kolangkaling is IDR7,000 kg-1 which means from one aren tree, the aren farmers get economic benefits from IDR700,000 month $^{-1}$ to IDR1,400,000 month ${ }^{-1}$. Farmers' income from harvesting kolang-kaling is lower when compared to local standard income in Jember (IDR2,355,662.90 month ${ }^{-1}$ ), which causes the community only consider taking kolangkaling as a side job.

The utilization of aren by the community of Andongrejo Village has not been optimal, because the community of Andongrejo Village only utilize aren to produce kolangkaling, whereas all parts of aren (such as roots, stems, leaves, fronds, sap, nira water, and fruit) can be potentially used Aren root is beneficial as aphrodisiac, skin medicine, and smooth digestion (Febriyanti et al., 2017). Aren stems can produce flour (starch) obtained from the extraction of the central part of the stem. Aren flour (starch) used as food ingredients including cakes, cendol, meatballs, bakmi (noodle), bihun, sohun, and hun kwe (Lutoni, 1993). Aren leaves can be used as a wrapper for aren sugar (Lempang, 2012). Frond of aren can be used as flour, Tomohon people use aren frond flour as a traditional medicine to eliminate itching and burns on the skin (Sangi et al., 2012). Other parts of aren trees that can be utilized are male flowers that produce nira water to make aren sugar, soft drinks, vinegar, and alcohol (Porobaten et al., 2017). Ijuk aren can be used for the manufacture of house brooms and roof of cattle shed (Damanik et al., 2014). Aren fruit can be used as foliage that is widely used as a mixture of various types of food and drinks, and can launch bowel movements (Lutoni, 1993).

Conservation efforts Conservation efforts of aren have been carried out by Meru Betiri National Park management, the program is planting aren in rehabilitation zone. Unfortunately, aren planted by Meru Betiri National Park management are mostly dead. According to the interview result, the death of aren trees planted occurred due to the limitation of water irrigation. The planning of aren planting program in rehabilitation zone needs to be reviewed to achieve the expected results. Preparation of planting programs should consider the availability of water on the land and the types of plants that are selected by the community, as a result that the community has the desire to care for the plants. Furthermore, assistance and intensive coaching to the community is required.

The community of Andongrejo Village has unconsciously conserved aren species together with the ecosystem. Conservation of aren carried out by selecting aren fruit which is ready for harvest and they only take aren which is located on a sloping area. Logically, aren found at a steep location is difficult to take however by leaving the species in steep or hills mean the importance of the presence of aren trees as a conservation function plant, erosion prevention trees or landslides, that need attention to be seriously developed or cultivated by various parties (Mulyanie \& Romdani, 2017).

Conservation strategy Considering the current condition of the utilization of aren in Andongrejo, a conservation strategy is formulated. Andongrejo Village community has used aren for a long time as a commercial plant. In the past, the community utilized aren to take the nira water to be processed into sugar. However, currently, the community only utilizes aren fruits as kolang-kaling.

According to Puspaningrum (2015), the main job of the community around Meru Betiri National Park was aren farmer. Nevertheless, the utilization of aren has not become the main occupation anymore because the community has begun to shift as field farmers who plant rice, corn, chilli, and other horticultural crops. The surrounding community utilizes aren directly from nature, yet without its cultivation. This can result the natural population of aren seems to be smaller and threatened. The population tend to run out due to nothing cultivation effort. Harvesting aren fruit is also considered to have an indirect negative effect on the productivity of nira water and aren regeneration (Martini \& Roshetko, 2012).

Based on the interview result, the ideal conditions expected by the community are the existence of aren plant cultivation, optimally utilizing aren, increasing the community interest in aren, the system of selling aren products directly to buyers, and cooperation and assistance from the government and national park managers. To achieve these ideal conditions, it is necessary to conserve aren. The precondition for the realization of successful conservation is the creation of attitudes and behaviors that are strongly driven by Tri-Stimulus Amar Pro Konservasi: crystallization or the unity of natural stimulus (stimulus alami), benefit stimulus (stimulus manfaat), and religiouswilling stimulus (sitimulus religius-rela) (Zuhud, 2007). Conservation actions that can be taken to achieve ideal conditions based on current conditions that refer to the TriStimulus Amar Pro Konservasi, among others aren cultivation with agroforestry systems, increase the value of aren, intensive coaching of aren farmers, and forming a group of aren farmers (Figure 4).

The main problem in the development of aren is the lack of interest in the surrounding community to utilize aren optimally. That is because the condition at the research location of the aren plant grows naturally is on sloping land which is quite steep. This condition makes some people less interested to go to the location of the aren plant since they must pass valley or ravine. Aren commodity development strategies must think of aren cultivation that can be done by the community so that people do not only rely on aren that grows naturally in the forest. Most people have not cultivated aren properly and only rely on aren that grows naturally without any serious maintenance and is focused on the usual use, as well as with the government, so far the government's programs and policies in developing aren are still very limited (Widyawati, 2011). The development of aren cultivation requires collaboration from various parties such as the community, the government, and the management of 


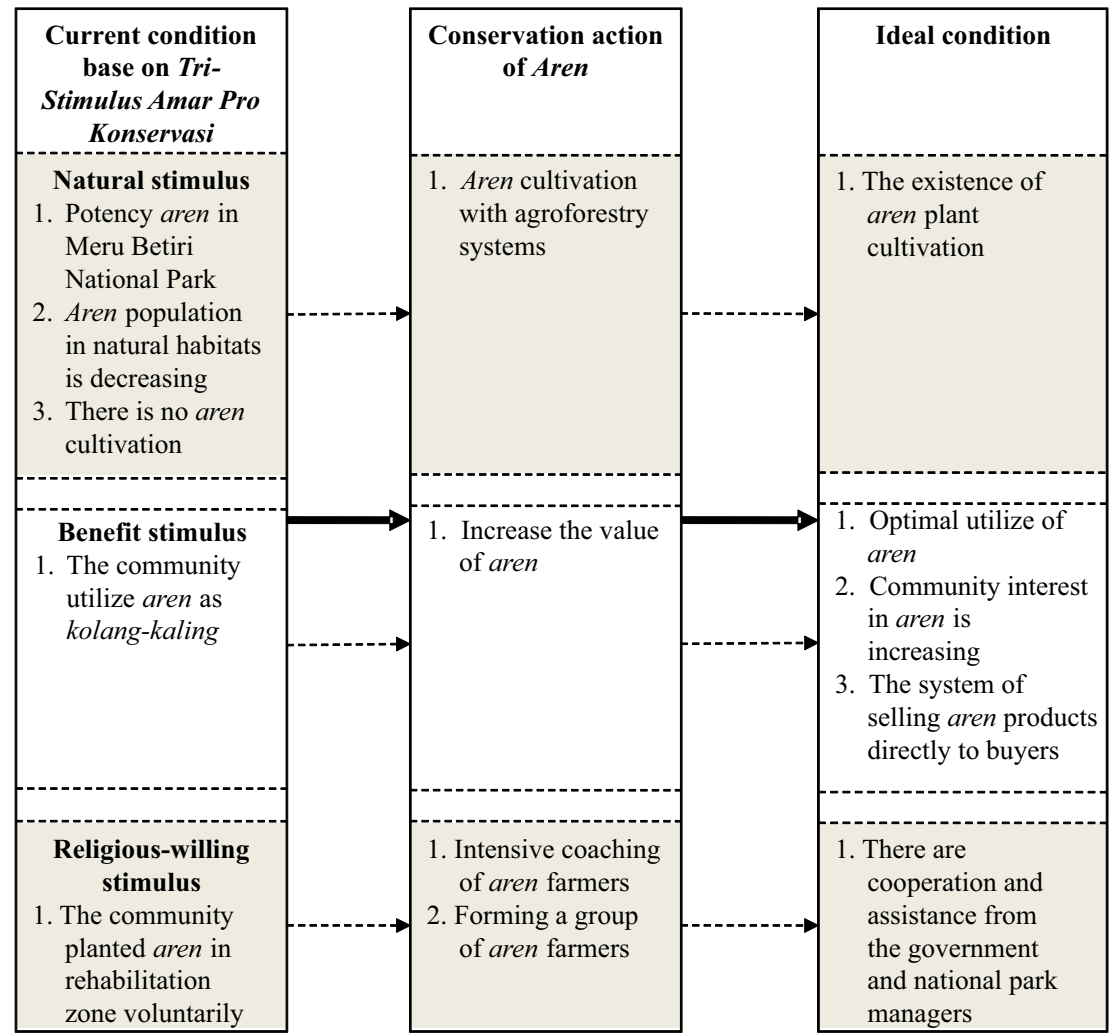

Figure 4 Conservation strategy of aren in Meru Betiri National Park.

the national park. Assistance to the community is needed to improve the success of the aren cultivation business conducted by the community. The development and cultivation of aren plants will have good prospects if it has been programmed well and planned early on.

Aren cultivation by the community can be developed with an agroforestry system, for example, by making a combination of aren trees with other plants that have economic value. Aren is a plant that is tolerant of other plants (Effendi, 2010). In the development of aren agroforestry, the attention must be paid to the nature of aren trees that are tolerant of shade. The activity of planting aren must be preceded by other plants to shade aren plants that will be planted. Aren cultivation within agroforestry systems can be combined with plants found in the natural habitat of aren and have economic value. Aren also can be combined with agricultural crops planted by the community of Andongrejo Village. Agroforestry management between aren and agricultural crops provides improved household income in Kampung Makian, South Halmahera (Tamrin et al., 2015).

The thing that must be considered in the efforts of cultivating aren is determining the distance of aren planting so that the planted plants can grow well. One method in minimizing soil nutrition absorption competition is by planting distance regulation, which is $9 \mathrm{~m} \times 9 \mathrm{~m}$ for aren (Sunanto, 1993). Plant spacing will affect the effectiveness of nutrient absorption by plants. The denser plant spacing, the more plant population per unit area, resulting the tight nutrient competition between plants. As a result, plant growth will be disrupted and production per plant will be declined (Mawazin \& Suhaendi, 2008).

Large aren plant spacing will have an impact on the surrounding environment such as reducing a number of plant populations and also causing reduced use of sunlight, and nutrients by plants, because some of light will fall to the ground and nutrients will be lost due to evaporation and washing (Erawati \& Hipi, 2017). Agroforestry between aren plants and plants from their natural habitat can be combined with corn to get the benefits of optimal economic value. Corn can be planted among aren that are cultivated to prevent evaporation and leaching of soil nutrient nutrients. In addition, corn are plants that are of interest to the community of Andongrejo Village.

Aren planting was carried out by the community with the Meru Betiri National Park management in rehabilitation zone. However, the plant did not grow well and eventually died. Based on the results of interviews with the manager of the national park, the large of aren planting in rehabilitation zone is unknown. It also makes it difficult to monitor the results of planting. To improve the welfare of the community, it is necessary to cultivate aren in the rehabilitation zone which is divided based on management blocks for each member of the farmer group.

Aren development strategy aims to optimize the utilization of all parts of aren plant by the community. If the community only use kolang-kaling, the economic income that they can get is IDR700,000 month $^{-1}$ to IDR 1,400,000 month $^{-1}$. Research conducted by Aulin (2019) shows that the 
income of the community who use nira water to be processed into aren sugar is IDR520,000 month $^{-1}$ to IDR3,120,000 month ${ }^{-1}$, depending on the intensity of taking nira water. Optimal utilization of aren can be achieved if the community has a high interest in aren plants, so it is necessary to increase the value of aren commodity not limited only as kolangkaling. Aren plant is a commodity with high economic value, so it has a great prospective to be developed and improved the economy of a region (Purba et al., 2014). If the community is aware on the economic benefits of aren, they will be ready to preserve aren. Conservation strategy that can be taken to preserve aren is to increase the value of aren by optimizing the utilization of aren. Realizing that aren is an economically profitable commodity, the community will pay more attention to the cultivation of aren. Aren trees also have an important role in ecological functions. The ecological function of aren tree is as a preservative of natural resources, especially land. The roots of aren tree are very sturdy, deep, and strong so that they have an important function as a barrier to soil erosion. In addition, aren roots can bind water (Yuldiati et al., 2016). Aren plants produce biomass above the ground and in very large soils that play an important role in the $\mathrm{CO}_{2}$ cycle (Effendi, 2010).

Aren is a commodity that has good development prospects because all parts of aren plant can be utilized in manufacturing. Aren can be developed to meet the needs of the sugar industry in Indonesia, as aren produces nira water from its tapped male flowers. The development of aren plant has good prospects, if it has been well programmed and planned (Widarawati et al., 2017). So far, aren in the Meru Betiri National Park area is only utilized in the form of fruits to be kolang-kaling, even though aren has the potential to be utilized in the form of nira water, ijuk, leaves, and sago, which can improve the economy of the surrounding community.

The economic benefits of aren is obtained from almost all their physical and production parts (Lempang, 2012). Some products from aren are needed by the international market so that to increase the value of exports which has an impact on improving the national economy. Aren products that have the greatest economic value right now are aren sugar. Aren sugar has a high selling value and has a fairly large market share, both in the domestic and export markets (Heryani, 2016).

Community education and empowerment are essential to be conducted to achieve the ecological and economic sustainability of aren plant in Meru Betiri National Park. At present, the community only carries out the harvesting of aren directly in nature and has not yet made an aren cultivation efforts. If this is done continuously, then aren will be difficult to find in the future, threatened its preservation in nature. The age of aren harvest is quite long, between 7-12 years, so that the cultivation of aren is needed through education and community empowerment to maintain the sustainability of aren in the future (Manaroinsong, 2006). Educating the community about aren cultivation techniques is needed due to limited information about the cultivation of aren trees.

Community empowerment is an effort to improve the economic condition of a community that starts from inadequate and then becomes able rise up from the pitfalls of poverty (Sutaryono, 2008). Community empowerment activities around Meru Betiri National Park through the optimal utilization and activities of aren cultivation, is expected to improve the economy and quality of life of the community. Factors that influence people's behaviour towards the preservation of forest resources consist of internal and external factors. Internal factors include age, income level, length of stay, level of interaction, level of education, level of tenure of agricultural land, and level of interaction with forests. External factors include the level of interaction with officers and membership in farmer groups (Garnadi, 2004; Wahyudi, 2004). Community empowerment requires collaboration from various parties involved in the process of community empowerment such as the government, community organizations (NGOs), community institutions, cooperatives, and assistants (Yansen, 2013).

\section{Conclusion}

Aren regeneration in Meru Betiri National Park is categorized stable because the total number of seedlings is higher than saplings, poles, and trees and seems to be decreased. The use of aren by the community of Andongrejo Village is limited only in the form of fruit as kolang-kaling. There is a gap between current conditions and ideal conditions for achieving aren sustainability. To achieve ideal conditions, are needed conservation actions based on TriStimulus Amar Pro Konservasi (natural stimulus, benefit stimulus, and religious-willing stimulus) among others aren farmers with agroforestry systems, increase the value of aren, intensive coaching of aren farmers, and forming a group of aren farmers.

\section{Acknowledgment}

We would like to thank Meru Betiri National Park management who guided us to conduct the field research. This paper was presented at the $2^{\text {nd }}$ International Conference on Environment and Forests Conservation in Bogor, Indonesia, on 13 October 2019.

\section{References}

Alam, S., \& Suhartati. (2000). Pengusahaan hutan aren rakyat di Desa Umpunge Kecamatan Lalabata Kabupaten Soppeng Sulawesi Selatan. Buletin Penelitian Kehutanan, 6, 59-70.

Arrijani, Setiadi, D., Guhardja, E., \& Qayim, I. (2006). Analisis vegetasi hulu DAS Cianjur Taman Nasional Gunung Gede-Pangrango. Biodiversitas, 7(2), 147-153. https://doi.org/10.13057/biodiv/d070212

Aulin, F. R. (2019). Nilai ekonomi, analisis pemasaran dan kelayakan aren (Arenga pinnata Merr) oleh masyarakat di sekitar kawasan Taman Nasional Batang Gadis [thesis]. Medan: University of Sumatera Utara.

[BTNMB] Balai Taman Nasional Meru Betiri. (2009). Identifikasi dan inventarisasi banteng terpadu 3 SPTN [report]. Jember: Balai Taman Nasional Meru Betiri.

Damanik, R., Azhar, I., \& Riswan. (2014). Inventarisasi dan pemanfaatan aren (Arenga pinnata Merr) oleh masyarakat sekitar hutan (Studi kasus: Hutan produksi 
terbatas Desa Sihombu, Kec. Tarabintang, Kab. Humbang Husundutan). Retrieved from https://jurnal.usu.ac.id/index.php/PFSJ/article/downloa d/7570/3213.pdf

Dransfield, J., Uhl, N. W., Asmussen, C. B., Baker, W. J., Harley, M. M., \& Lewis, C. E. (2014). Genera Palmarum: The evolution and classification of palms. New York: International Palm Society and The L.H. Bailey Hortorium, Cornell University.

Effendi, D. S. (2010). Prospek pengembangan tanaman aren (Arenga pinnata Merr) mendukung kebutuhan bioetanol di Indonesia. Perspektif, 9, 36-46.

Erawati, B. T. R., \& Hipi, A. (2017). Pengaruh jarak tanam terhadap pertumbuhan dan hasil beberapa varietas jagung hibrida di kawasan pengembangan jagung Kabupaten Sumbawa. Prosiding Seminar Nasional Inovasi Teknologi Pertanian Spesifik Lokasi, Banjarbaru, 20 Juli 2016.

Ewusie, J. Y. (1990). Ekologi tropika. Bandung: Penerbit ITB.

Febriyanti, N. (2017). Etnobotani dan potensi aren (Arenga pinnata Merr.) pada masyarakat Kasepuhan Pasir Eurih, Desa Sindanglaya, Kabupaten Lebak, Banten [thesis]. Bogor: IPB University.

Febriyanti, N., Agus, H., \& Zuhud, E. A. M. (2017). Etnobotani dan potensi aren (Arenga pinnata Merr.) pada masyarakat Kasepuhan Pasir Eurih, Desa Sindanglaya, Kabupaten Lebak, Banten. Media Konservasi, 22(2), 171-180. https://doi.org/10.29244/medkon.22.2.171180

Garnadi, D. (2004). Pengetahuan, sikap, dan tindakan masyarakat sekitar hutan terhadap hutan (Kasus di Hutan Pendidikan dan Pelatihan Kehutanan Kadipaten, Kabupaten Majalengka) [thesis]. Bogor: IPB University.

Gunawan, R., Ramadhan, U. G., Iskandar, J., \& Partasasmita, R. (2018). Local knowledge of utilization and management of sugar palm (Arenga pinnata) among Cipanggulaan People of Karyamukti, Cianjur (West Java, Indonesia). Biodiversitas, 19, 93-105. https://doi.org/ 10.13057/biodiv/d190115

Haryoso, A., Zuhud, E. A. M., Hikmat, A., Sunkar, A., \& Darusman, D. (2020). Ecological aspects and regeneration of sugar palm in the Sasak community gardens of Kekait Village, West Nusa Tenggara, Indonesia. Jurnal Manajemen Hutan Tropika, 26(1), 1-12. https://doi.org/10.7226/jtfm.26.1.1

Heryani, H. (2016). Keutamaan gula aren dan strategi pengembagan produk. Banjarmasin: Lambung Mangkurat University Press.

Ishak, M. R., Sapuan, S. M., Leman, Z., Rahman, M. Z. A., Anwar, U. M. K., \& Siregar, J. P. (2013). Sugar palm
(Arenga pinnata): Its fibers, polymers and composites. Carbohydrate Polymers, 91, 699-710. https://doi.org/10. 1016/j.carbpol.2012.07.073

[Kemenhut] Kementerian Kehutanan Republik Indonesia. (2007). Peraturan Menteri Kehutanan Republik Indonesia Nomor P.35/Menhut/2007 tentang Hasil Hutan Bukan Kayu. Jakarta: Kementerian Kehutanan Republik Indonesia.

[Kementan] Kementerian Pertanian Republik Indonesia. (2013). Peraturan Menteri Pertanian Republik Indonesia Nomor 133/Permentan/OT.140/12/2013 tentang Pedoman Budidaya Aren (Arenga pinnata MERR) yang Baik. Jakarta: Kementerian Pertanian Republik Indonesia.

[KLHK] Kementerian Lingkungan Hidup dan Kehutanan Republik Indonesia. (2015). Peraturan Menteri Lingkungan Hidup dan Kehutanan Republik Indonesia Nomor P.76/Menlhk-Setjen/2015 tentang Kriteria Zona Pengelolaan Taman Nasional dan Blok Pengelolaan Cagar Alam, Suaka Margasatwa, Taman Hutan Raya dan Taman Wisata Alam. Jakarta: Kementerian Lingkungan Hidup dan Kehutanan Republik Indonesia.

Krebs, C. J. (1989). Ecological methodology. New York: NY Harper and Row Publishers Inc.

Lay, A., \& Karouw, S. (2006). Nira aren dan teknik pengendalian produk olahan. Buletin Palma, 31, $116-125$

Lempang, M. (2012). Pohon aren dan manfaat produksinya. Info Teknis EBONI, 9, 3754

Ludwig, J. A., \& Reynold, J. F. (1988). Statistical ecology. New York: John Wiley and Sons.

Lutoni, T. L. (1993). Tanaman sumber pemanis. Jakarta: Penebar Swadaya.

Manaroinsong, E., Maliangkay, R. B., \& Matana, Y. R. (2006). Observasi produksi nira aren (Arenga pinnata) di Kecamatan Langowan, Kabupaten Minahasa Induk, Provinsi Sulawesi Utara. Buletin Palma, 31, 111-115.

Martini, E., \& Roshetko, J. M. (2012). Aren (Arenga pinnata (Wurmb) Merr.) traditional management system in Batang Toru, North Sumatra and Tomohon, North Sulawesi, Indonesia. Proceedings of International Conference of Indonesia Forestry Researchers, (pp. 552-561). Bogor, December 5-7, 2011.

Mawazin, \& Suhaendi, H. (2008). Pengaruh jarak tanam terhadap pertumbuhan diameter Shorea parvifolia Dyer. Jurnal Penelitian Hutan dan Konservasi Alam, 5, 381-388. https://doi.org/10.20886/jphka.2008.5.4.381388

Muda, N. A., Awal, N., Abdullah, M. H., \& Abdullah, S. (2016). Embryogenic callus induction of Arenga pinnata 
Wurmb Merr. (sugar palm) from basal stem explant. Int'l Journal of Advances in Agricultural \& Environmental Engineering, 3(1), 106-109. https://doi.org/10.15242/ IJAAEE.AE0216127

Mulyanie, E., \& Romdani, A. (2017). Pohon aren sebagai tanaman fungsi konservasi. Jurnal Geografi, 14, 11-17. https://doi.org/10.15294/jg.v14i2.11514

Pongsattayapipat, R., \& Barfod, A. S. (2009). Economic botany of sugar palms (Arenga pinnata Merr. and $A$. westerhoutii Griff., Arecaceae) in Thailand. Thai Journal of Botany, 1, 103-117.

Porobaten, E., Laoh, O. E. H., \& Waney, N. F. L. (2017). Analisis pendapatan usaha gula aren di Dusun Kalatin, Kecamatan Ratahan Kabupaten Minahasa Tenggara. Agri-Sosio Ekonomi, 13, 39-50. https://doi.org/10. 35791/agrsosek.13.3A.2017.18015

Purba, E., Affandi, O., \& Asmono, L. P. (2014). Nilai ekonomi dan sebaran aren (Arenga pinnata) di Desa Bukum dan Desa Suka Maju, Kecamatan Sibolangit. Peronema Forestry Science Journal, 3, 18.

Purwati, \& Nugrahini, T. (2018). Pemanfaatan buah kolangkaling dari hasil perkebunan sebagai pangan fungsional. Jurnal Abdimas Mahakam, 2, 25-33. https://doi.org/10. 24903/jam.v2i1.291

Puspaningrum, D. (2015). Kearifan lokal dalam pengelolaan sumberdaya alam hutan dan ekosistem (SDHAE) pada masyarakat desa penyangga Taman Nasional Meru Betiri. Journal of Social and Agricultural Economics, 8, 11-24.

Sahari, J., Sapuan, S. M., Zainudin, E. S., \& Maleque, M. A. (2013). Thermo-mechanical behaviors of thermoplastic starch derived from sugar palm tree (Arenga pinnata). Carbohydrate Polymers, 92, 1711-1716. https://doi.org/ 10.1016/j.carbpol.2012.11.031

Sangi, M. S., Momuat, L. I., \& Kumaunang, M. (2012). Uji toksisitas dan skrining fitokimia tepung gabah pelepah aren (Arenga pinnata). Jurnal Ilmiah Sains, 12, 127-134. https://doi.org/10.1234/jis.v12i2.716

Setia, T. M. (2008). Penyebaran biji oleh satwa liar di Kawasan Pusat Pendidikan Konservasi Alam Bodogol dan Pusat Riset Bodogol, Taman Nasional Gunung Gede Pangrango, Jawa Barat. Vis Vitalis, 1, 18.

Shankar, U. (2001). A case of high tree diversity in a sal (Shorea robusta)-dominated lowland forest of Eastern Himalaya: Floristic composition, regeneration and conservation. Current Science, 81, 776-786.

Soeseno, S. (1991). Bertanam aren. Jakarta: Penebar Swadaya.

Sovia, E., \& Anggraeny, D. (2019). Sugar palm fruits (Arenga pinnata) as potential analgesics and anti- inflammatory agent. Molecular and Cellular Biomedical Sciences, 3(2), 107-114. https://doi.org/10.21705/ mcbs.v3i2.63

Sugihartono. (2007). Psikologi pendidikan. Yogyakarta: UNY Press.

Sugiyono. (2017). Metode penelitian kualitatif, kuantitatif, dan $R \& D$. Bandung: Alfabeta.

Sumarni, G., Ismanto, A., \& Muslich, M. (2003). Keawetan batang aren (Arenga pinnata Merr.). Jurnal Penelitian Hasil Hutan, 21, 167-173. https://doi.org/10.20886/ jphh.2003.21.2.167-173

Sunanto, H. (1993). Aren budidaya dan multigunanya. Yogyakarta: Penerbit Kanisius.

Surasana, E. S., \& Taufikurrahman. (1994). Pengantar ekologi tumbuhan. Bandung: ITB.

Sutaryono. (2008). Pemberdayaan setengah hati: Subordinasi masyarakat lokal dalam pengelolaan hutan. Yogyakarta: STPN \& Lapera Pustaka Utama.

Tamrin, M., Sundawati, L., \& Wijayanto, N. (2015). Strategi pengelolaan agroforestri berbasis aren di Pulau Bacan Kabupaten Halmahera Selatan. Jurnal Risalah Kebijakan Pertanian dan Lingkungan, 2, 243-253. https://doi.org/ 10.20957/jkebijakan.v2i3.12577

Wahyudi, S. (2004). Perilaku komunikasi anggota masyarakat sekitar hutan terhadap pelestarian hutan (Kasus di Hutan Pendidikan dan Pelatihan Bukit Suligi, Kabupaten Rokan Hulu, Riau) [thesis]. Bogor: IPB University.

Wanggai, F. (2009). Manajemen hutan: Pengelolaan sumberdaya hutan secara berkelanjutan. Jakarta: Grasindo.

Weisz, P. P. (1959). The science of biology. New York: McGraw-Hill Book Company Inc.

Widarawati, R., Yudono, P., Indradewa, D., \& Utami, S. N. H. (2017). Sifat dan karakteristik tanah yang memengaruhi pertumbuhan tanaman aren (Arenga pinnata (Wurmb.) Merr). Jurnal Pertanian Agros, 19, 55-60.

Widyawati, N. (2011). Sukses investasi masa depan dengan bertanam pohon aren. Yogyakarta: Lily Publisher.

Yansen, T. D. (2013). Gerakan desa membangun. Malang: Danar Wijaya.

Yuldiati, M., Saam, Z., \& Mubarak. (2016). Kearifan lokal masyarakat dalam pemanfaatan pohon enau di Desa Siberakun Kecamatan Benai Kabupaten Kuantan Singingi. Dinamika Lingkungan Indonesia, 3, 77-81. https://doi.org/10.31258/dli.3.2.p.77-81

Yusof, Z., \& El Pebrian, D. (2016). Analysis of human energy expenditure in harvesting sugar palm (Arenga pinnata 
Merr) in Malaysia. Agricicultural Engineering International: CIGR Journal, 18, 149-157.

Zuhud, E. A. M. (2007). Sikap masyarakat dan konservasi, suatu analisis kedawung (Parkia timoriana (DC) Merr.), sebagai stimulus tumbuhan obat bagi masyarakat, kasus di Taman Nasional Meru Betiri [dissertation]. Bogor: IPB University. 